\title{
Pattern and Chaos: Ralph Ellison and the Federal Writers' Project
}

\section{J. J. Butts}

Beginning with its "mazelike" underground journey to reach the Lafargue Psychiatric Clinic, Ralph Ellison's 1948 essay "Harlem Is Nowhere" spins out a series of "surreal fantasies" in sketching "a character that arises from the impact between urban slum conditions and folk sensibilities." Many Harlemites refer to their neighborhood as "nowhere," the essay explains, because of the feeling that "they have no stable, recognized place in society. . . . One 'is' literally, but one is nowhere; one wanders dazed in a ghetto maze, a 'displaced person' of American democracy." ${ }^{2}$ Lamenting this displacement, at once social and psychological, the essay prefigures the notion of invisibility in the novel Ellison was writing at the same time.

\section{What Kind of Citizen Could Come from Nowhere?}

This question has offered one of the key fault lines in critical approaches to Invisible Man. Should readers take seriously the narrator's claim in the epilogue that "there's a possibility that even an invisible man has a socially responsible role to play," or is this claim a kind of "buggy jiving"? 3 The details of Ellison's employment with the Federal Writers Project (FWP) - a unique, socially transformative moment in which he participated on a project designed to encourage participatory citizenship - offer useful perspective. While it kept a generation writing and engaged in the business of cataloguing and describing "American 
stuff" during the Depression, the FWP particularly offered several African American writers - including Ellison, Zora Neale Hurston, Claude McKay, Roi Ottley, Ellen Tarry, Rebecca West, and Richard Wright, among others - a literary home during the 1930s in the wake of the Harlem Renaissance. Though many writers resented their work reporting what must have at times seemed like utterly mundane minutia, Ellison utilized both historical and folk material generated by his FWP investigations to write Invisible Man. He openly recognized his debt in a 1977 interview with Ann Banks:

For me, being on the Writers' Project was a way to broaden my knowledge of Afro-American culture. I'd always liked the stories and things, and I couldn't hear enough of them, so this was throwing me into my own history. Once you touched the history of blacks in New York then you were deep into American history. ${ }^{4}$

Ellison's reminiscent evaluation captures an important dynamic of Invisible Man reflected in its final claim about "lower frequencies": 5 the difference between awareness of American history and "touching" the materials that form its "deep" elements.

In Invisible Man, Ellison utilized material from his FWP tenure to critique the foundations of utopian progressive thought, placing in its stead a critical liberalism, one that was anti-utopian and much more cautious in outlook than much postwar liberalism and, most importantly, emphasized local knowledges and claims on justice against broader plans for reform and modernization. The ideal citizen of the New Deal welfare state as imagined in its documents was historically knowledgeable, socially progressive, and oriented toward modernization. Ellison's work bracketed each of those ideals, highlighting the ways that positivist overconfidence tended to downplay important stories and disguise prejudice, and thus elided crucial elements of ongoing dispossession. While a new interpretation of Invisible Man is not the aim of this essay, a focus on the New Deal and its cultural activity illuminates a broader field of discourses within liberalism with which Ellison was engaged. In particular, Invisible Man's deployment of vernacular culture and history attacks the underpinnings of planning and development advanced by the FWP and other New Deal agencies, discourses central to the New Deal national imaginary before the Second World War and to an international one afterwards. ${ }^{6}$

Though widely recognized as a formative experience, the New Deal remains relatively under-analyzed in studies of Ellison. Many critics read Ellison's engagement with Wright and the interwar Left as his key intellectual context in the 1930s and 1940s. ${ }^{7}$ By contrast, discussions of citizenship as a theme in Invisible Man focus primarily on Cold War liberalism. Both perspectives downplay his FWP apprenticeship and flatten the political field of liberalism. Even the critics who have focused on Ellison's FWP work have paid more 
attention to cultural debates about the folk than to broader political dynamics of the emergent welfare state. ${ }^{8}$ These gaps offer an opportunity to reexamine Ellison's activities while on the project, to resituate Invisible Man in the nexus of that work and the other books written out of the FWP experience, and to see where Invisible Man corresponded with other New Deal discourses. Correspondence functions doubly here, both in the sense of a dialogue pursued at uneven intervals through writing, but more importantly as a relationship in which causality remains undefined. As Michael Szalay, Susan Edmunds, and Sean McCann have illustrated, literature's engagement with welfare state liberalism was often indirect, enacted though metaphor and displacement. ${ }^{9}$ This engagement is rarely seen in isolation but instead is most visible when these texts are considered in dialogue with other narrative forms, including documentary literature and film. Ellison's novel calls into question the recognized causal patterns of historical narrative, opening up other modes of connection, both historical and symbolic.

\section{Federal Writer No. 700846}

Ellison applied for Works Progress Administration (WPA) relief status in 1937 and was hired in June of 1938. His duties: "To gather historical, cultural, commercial, educational, and other data for presentation to the staff editor as a comprehensive, authoritative, well-written survey of the subject assigned."10 As opposed to writers like Maxwell Bodenheim, Claude McKay, and Anzia Yezierska - who had already established their reputations, fallen on hard times, and often felt ambivalence about the Project's primary work-Ellison's reportorial, editorial, and public relations writing experience, indicated by his letters of reference, fit well with the Project's aims. ${ }^{11}$ Rampersad characterizes Ellison as adept at navigating the complex politics of the New York FWP office, where labor struggles, political factionalism, and anxiety over the continuance of the Project fueled everyday interpersonal disputes. ${ }^{12}$

Since Ellison joined the FWP relatively late, he had missed much of the work on its major project, the two-volume guidebook to New York City for the American Guide series. In addition to general editorial work, most of Ellison's tasks fell into two categories: research and reporting for the Negro History subunit and its project The Negro in New York; and interviews and research on urban folklore for Nicholas Wirth's Living Lore subproject. Of these, Ellison's work for the Living Lore project is the most well-known influence on his writing. Heavily shaped by the ideas of Benjamin Botkin, this project rejected the idea of folklore as an anachronism, whether as a fading holdover from the past or, as John Lomax had argued, a residual cultural resistance to industrial capitalism. Against these, the unit demonstrated that folklore was being re-outfitted for urban existence, and new folkways were emerging within urban life. ${ }^{13}$ The productive presence of vernacular culture was a crucial insight for Invisible Man, and documented Living Lore moments are visible throughout the text: in 
the chant about Buckeye the Rabbit that Ellison heard on a Harlem playground; in the story of the invisible trickster "Sweet-the-Monkey" told to Ellison by Leo Gurley; in the famous excised chapter in which Mary Rambo talks about being in New York without New York being in her, a line Ellison recorded in an anonymous oral interview in 1939 at Eddie's Bar. ${ }^{14}$

The current framework for understanding such inclusions does not fully account for Ellison's engagement with the New Deal cultural apparatus. Though it consumed more of his time, Ellison's work for the Negro History subunit has generally been given less recognition than his work on folklore. In part, this occurs not only because the historical work does not initially seem to connect as directly and clearly to the narrative dynamics of his most famous novel as the Living Lore does but also because that unit's activities have not been as well analyzed as others in the context of the FWP and the New Deal. The Living Lore and other New Deal folk projects yielded insights about culture and, more importantly, documents in the form of oral histories, songs, and stories that formed the basis of much of postwar American popular culture and counterculture, as well as the memory/recovery of African American culture. Since The Negro in New York remained unpublished until 1967, it could not have the same direct impact. The immediate legacy of the Negro History unit lies indirectly, though not insignificantly, in the florescence of diagnostic sociological studies of African America drawing on its research. ${ }^{15}$ However, writers on that subunit were just as engaged in the inter-New Deal dialogue about the direction of modernity and citizenship as the folklorists were. ${ }^{16}$

A quick scan of Ellison's Negro History project assignment titles- "Short story of Negroes of New York on swimming as an amusement"; "Problems of early Negroes during English occupation, etc."; "Short history of Dutch using Negroes to fight Indians"; "Trace deed of Madison Square to the city by one Annie Angola"-seems scattershot. However, as the 1977 interview suggests, he was developing an alternate notion of American history, one in which African Americans are active participants even while their participation and presence are expunged from historical narratives. Ellison would have been aware of this dynamic before his FWP employment, but the concentration of stories he found in his research would have enabled him to make connections between the folk narratives and historical counternarrative. One of his oral histories demonstrated this by charting a course through American history centered on the sinking of the Titanic - in folklore a comeuppance for racial exclusion - in which George Washington actively worked to suppress African Americans and the coming World War, serving as a reminder of the limits of white civilization. ${ }^{17}$

Ellison's work in both units put him at the intersection of discourses of modernity (what belongs to the present and distinguishes it from the past) and modernization (the processes by which a future-oriented nation and citizenry could be achieved). What the two projects shared was an assertion of the continuous presence of African American culture that ultimately conflicted with the narrative of development advanced in the American Guides. The American 
Guide series promoted a particular vision of the New Deal and how it could shape the nation and its citizenry. ${ }^{18}$ New Deal liberalism was shaped by a tension among several poles: social insurance, cultural pluralism, and planned modernization. Moreover, the conflicting, passionate beliefs of administrators ran headlong into political interests and pragmatism during the development of New Deal programs. Though the eventual ascendance of social insurance as the keystone of surviving New Deal programs in the postwar era has led some historians to suggest a break between the New Deal and earlier social movements, nearly all of these ideas were Progressive imports into the New Deal, and all of them lived into the postwar era. ${ }^{19}$ Instead of a generative conceptual break, the New Deal is best viewed as the incorporation of these disparate ideas within the state apparatus and the transformation of that apparatus and the social body it governs through them. While Keynesian ideas about social insurance eventually formed the backbone of the welfare state, they are remarkably muted in the cultural documents produced by the federal government during that period. In contrast, both pluralism and planning are front and center in New Deal cultural projects. Essentially, the tension between pluralism and planning boiled down to questions of modernity and agency. Which elements would be recognized as belonging to the future, and which would be seen as retrograde? Who would make decisions about the direction of development?

These questions all bear on New Deal conceptions of citizenship and their influence on postwar liberalism. The later New Deal programs in their most Keynesian manifestation imagined citizens as members of relatively passive individual or family consumption units, while the government and corporations would determine the realm of available choices. The progressives who influenced the New Deal had much more in mind, envisioning knowledgeable, active participants in politics, community life, work, and even consumer activities. Many of them wanted an inclusive, pluralist understanding of citizenship, but they primarily sought a more robust one. The government could help make this possible by creating communities in which such active citizens might flourish. Crucial here is the future orientation insofar as it tends to substitute the potential community for the existing one. Faith in technological solutions to political problems also undercuts the more radical potential of the progressive vision by substituting utilitarian efficiency for political disagreement. While postwar American liberalism outwardly rejected utopianism in favor of more consumerist and cultural modes of participation, both at home and abroad it still stressed development based on a narrow set of norms with the state as a key agent as the most effective means of building good citizens.

While WPA federal and state offices gave support to projects that told diverse American stories on a local level, these were often subsumed into a national narrative of development in which the future was brought about by a series of well-planned interventions. The descriptions offered little recognition of the tensions between federal development aims and the spatial and social primacy of localized groups. The discourse of development is most evident in 
the structure of Pare Lorentz's famous documentaries for the New Deal Resettlement Administration, The Plow That Broke the Plains and The River, in which the piecemeal land use that contributed to environmental crises like the Dust Bowl and Mississippi River flooding is supplanted by well-planned and coordinated federal interventions that lead to modernization in the form of flood control and hydropower. ${ }^{20}$ Such interventions were expected to bring underdeveloped regions of the country and their residents into the modern nation.

The vision of citizenship literally built through intervention included African Americans. Wright had written The WPA Guide to New York City's section on Harlem, which made a case for seeing the neighborhood problems as created by decades of injustice and as solvable by government action. A promotional bulletin entitled "WPA and the Negro," likely from 1937, put together by Director of Racial Relations James Ross, highlights such achievements as sewing units, the Emma Ransom House YWCA, and a YWCA Trade School. The bulletin reproduces a 1936 speech by Carita V. Roane about the Harlem River Houses project:

\begin{abstract}
Slum dwellers will leave ill-ventilated and unsanitary buildings and move into sunny apartments with playgrounds for children. . . . It is impossible to estimate the effect that these apartments will have upon the morale of the occupants. . . . In this community there will be, I should guess, a thousand children, and from this group we ought to have a thousand law-abiding citizens who will be an asset to the community. ${ }^{21}$
\end{abstract}

This same logic in which federal intervention builds citizenship and community is evident throughout the guidebooks, and one of the clearest examples emerges in The WPA Guide to New York City in its discussions of the Harlem River Houses along with other public housing projects that replaced tenements with modern housing amenities. Unambiguously positioned as one of the most notable achievements of the New Deal, the housing projects' existence is a marker of Progressive promises realized and a guarantee of future interventions. All too often in development narratives the building of a thing and its mission success are conflated. In what can only be read since the 1950 s as tragic irony, the guide prematurely highlights the absence of crime and the formation of "a compact progressive community" after the Harlem River Houses' first year. $^{22}$

The existence of a FWP subunit exploring African American culture and history mostly staffed by black writers offered a crucial opportunity to engage with this narrative and to offer caution and perspective. These writers were keenly aware that the FWP presented an unusual opportunity, if a tenuous one. Many politicians saw the Federal Arts projects in general as unnecessary work, and others feared that they would become a vehicle for propaganda. In addition, the FWP progressively employed African Americans in a relatively integrated 
white-collar workforce. A note from Roi Ottley while Ellison was laid up in the hospital wishes him "a quick recovery and speedy return to THE FELLOW BOONDOGGLERS." ${ }^{23}$ The joke ironically references condemnation of the project as a more sophisticated form of corruption and patronage. Such distance would have been important to handling the promises and disappointments of New Deal politics.

The Negro in New York project provided an opportunity to bring a critical lens to bear on three hundred years of African American life in New York. The eventually published version illustrates the distance between the development narrative promoted at the federal and state level and the writings of the local and ethnic subprojects. Up to a point, its account of Harlem accords that with the version in the FWP guidebooks. Harlem is figured as a created slum environment, with the Renaissance largely written out as a blip in the neighborhood's downward trajectory. However, The Negro in New York never offers the comprehensive, state-directed utopian vision authorized by the development narrative. Its muted support of New Deal intervention stands in sharp contrast with the championing of housing projects and other programs in the American Guides. This reconfiguration set the pattern for many writers looking at black urban neighborhoods during the postwar era.

During and after the Second World War, African American writers continued to offer critical accounts of the government's commitment to racial justice. Invisible Man participated in this broad literary conversation in which both fictional and nonfictional intertexts of the FWP developed perspectives and materials gathered during work on the Writers' Project to advance competing diagnoses of racial injustice and visions of the future. The legacy of the FWP can be seen in African American literature in at least three topoi: (1) the use of urban space as a measurement of the commitment of the federal government to including African Americans in the emerging national community, (2) the imagination of Harlem and other black neighborhoods as slums, and (3) a reconsideration of the relationship between urban culture and folk vernacular culture. ${ }^{24}$

If "Harlem Is Nowhere" had been published in the 1940s, it would have joined a host of New Deal intertexts by African American writers serving as diagnostics of urban black life. ${ }^{25}$ Arguably, Wright's Native Son is the most influential fictional work written on Roosevelt's dime. Like Native Son, 12 Million Black Voices, Wright's photobook using Farm Security Administration (FSA) photographs, highlights the process by which slum environments are created and maintained and the psychological effects of these environments. In both books, Wright essentially called for class-conscious alliances, while remaining wary of political programs that subordinated attention to the crucial role of race in maintaining oppression. Meanwhile, both Ottley and McKay - in New World A-Coming and Harlem: Black Metropolis, respectively—questioning the prevailing stories of demagoguery and sedition promoted by both white and black liberal intellectuals, recast post-Garveyite movements as both pragmatic 
activism and harbingers of the consequences of the nation's failure to address structural racial inequality. For Ottley in particular, rather than the wholesale redevelopment of urban neighborhoods, the aim of the government should be to make certain that African Americans were included in the economic opportunities presented by wartime industry. Though most of these texts helped to build the image of Harlem as a slum, by focusing on people rather than the physical environment, all indirectly offered ambivalent assessments of the development narrative. ${ }^{26}$

\section{Invisible Man and the Pattern of History}

Like other FWP intertexts, Invisible Man utilized research from the Writer's Project, but Ellison created a mythical urban landscape in which folk material directly intervenes in the present. Discussing his experience interviewing people for the project, Ellison noted, "You didn't have to encourage them too much before this stuff began to come out." 27 "Stuff" was a fairly popular phrase in the Federal Arts lexicon and served as a kind of folky, joking reference to the immense range of phenomena in American history and culture. ${ }^{28}$ Throughout the novel, the material presence of "stuff" in the form of folkways, historical objects, and other forms of vernacular culture calls into question historical narrative as an authoritative pattern giving shape to the past and present and authorizing specific interventions to ensure desired futures. Ellison the musician was well aware of the power of time as a patterning and disorganizing phenomenon. From the discussion of the local yokel beating the scientific boxer and the extratemporal powers of marijuana and jazz in the prologue to the surreal riot scene at the end, the novel is filled with references to slipping into a time outside the efficient beat of progress.

Two moments of temporal intrusion indebted to Ellison's FWP work mark the narrators' awakening from the shattered dream of Washingtonian uplift. In the factory-hospital scene, the narrator realizes:

Somehow I was Buckeye the Rabbit . . or had been, when as children we danced and sang barefoot in the dusty streets:

Buckeye the Rabbit

Shake it, shake it

Buckeye the Rabbit

Break it, break it . . . ${ }^{29}$

Though the chant is from the narrator's Southern hometown, Ellison picked it up verbatim from the playgrounds of Harlem. ${ }^{30}$ The moment collapses temporalities and spaces, and suddenly, the narrator is playing the dozens, the vernacular activity he had just dismissed as being beneath his dignity.

The power of fragmentary "stuff" returns when the narrator intervenes in the eviction scene where he first begins to use rhetoric as a tool of authority. It 
seems the power of objects compel him as he views the fragmented material of the elderly couple's past, objects with meanings unrecognized by the state that is unearthing and dispossessing them:

I turned and stared again at the jumble, no longer looking at what was before my eyes, but inwardly-outwardly, around a corner into the dark, far-away-and-long-ago, not so much of my own memory as of remembered words, of linked verbal echoes, images, heard even when not listening at home. And it was though I myself was being dispossessed of some painful yet precious thing that I could not bear to lose. . . ${ }^{31}$

If the factory-hospital scene is the point at which folkways bring the narrator to a new form of self-consciousness, the anachronistic congeries in the eviction scene in Harlem materialize the folk, allow the narrator to touch history and hail him as a citizen in a social body. Mark C. Conner contends that
[t]he things in Invisible Man do not simply exist in present time and space; rather they are portals to a larger concept of time, history, and identity than is otherwise available to the Invisible Man. . . . Ellison's objects do not merely point the Invisible Man toward a larger universe - they create that uni- verse and make it exist in the present moment. ${ }^{32}$

The narrator does not recognize their full import, only that he feels it necessary to act to prevent their loss. As it does in Walter Benjamin's "Theses on the Philosophy of History," the detritus of the past serves as a material record of the suppressed elements of history and invokes an intergenerational debt premised on justice. ${ }^{33}$

The contrast between Invisible Man and Wright's 12 Million Black Voices usefully illuminates the present-ness of history in Ellison's novel. Wright subtitled his work a "folk history," but throughout his book, he consistently discussed the folk as a residual element of agrarian society. For Wright, folkways were useful insofar as they provided a coded language of survival in agrarian environments and ameliorated suffering in urban ones. Invisible Man, by contrast, grants a continuously generative presence to vernacular culture. In 12 Million Black Voices, the move to urban environments begets a new generation of "Men in the Making," who ostensibly cast off folk knowledge for a greater understanding of their situation. In Invisible Man, this knowledge, drawn out by material remnants, "stuff," is precisely what makes the narrator able to engage with his environment in a way that evades its patterning.

Attacking history as a selective pattern one can follow to just outcomes is crucial to the book's conception of critical citizenship and its indirect critique of New Deal development narrative. The Brotherhood's "scientific history" serves 
as selective pattern's most visible form, but others fill the novel. The narrator's battle with "Monopolated Light \& Power" highlights power transfer hiding under the guise of modernization. ${ }^{34}$ As Alan Nadel argues, Ellison also took a shot at Progressive thinker and planner Lewis Mumford. ${ }^{35}$ While Mumford's The Golden Day is populated by free-thinking individuals asserting control of their own lives and thus realizing a republican ideal of citizenship, Ellison's bar bearing the same name is filled with veterans suffering physically and mentally who attempted to live up to national standards of citizenship. Mumford's focus on the preindustrial eras in most of his 1930s criticism was meant to remind the reader that a greater future was possible by reference to more organic past societies, while his utopian visions and activities as a critic and planner sought to call that future into being. Invisible Man reminds readers of the human toll of Mumford's celebrated era.

One problematic effect of such a negative view of history is that it might, as the narrator suggests in a semantic slip, encourage "Rinehartism-cynicism," thus undercutting any grounds for citizenship. ${ }^{36}$ "What if history was not a reasonable citizen," the narrator asks when he encounters Rinehart's zoot-suiters, "but a madman full of paranoid guile and these boys his agents, his big surprise! His own revenge?"37 The final riot scene, which the narrator unintentionally spurs, is crucial to both the novel's rejection of cynicism and the narrative's indirect critique of development. The Brotherhood's sudden disinvestment in the community inflames both black nationalist and more cynical passions and forms an interesting analogue with the role of the federal government in urban disinvestment. The FWP had blamed pre-New Deal leadership failures for the conditions leading to the 1935 Harlem riot, but Ellison had both the 1935 and 1943 Harlem riots as inspiration. ${ }^{38}$ Wartime scaling back of both the FWP and the New Deal's more ambitious community projects had begun to undercut what goodwill had been garnered. One figure representing disenchantment is Dupre, who, in the middle of the riot, attempts to burn the tenements, and who remains one of the more underrepresented figures in criticism of the novel despite his prominence as the last in the succession of figures the narrator encounters. George E. Kent contends

The dramatic and symbolic function of Dupre and his followers is to reflect the folk ability to move with poise amidst chaos and in contradiction to the flat rational assumptions of the Brotherhood concerning its mission as planners for others. The rioters move with a plan that directly confronts Reality. ${ }^{39}$

This nicely illustrates the possibility of folkways, but the primary aim in the arson is destruction of the offending structure; no thought is given to what will come next. Dupre's arson would achieve slum clearance with remarkable efficiency at little cost to the state. Within Rinehartism lies the possibility of smooth action, hidden and highly individual motives - a stylistic engagement 
for which the Brotherhood has no category. While Rinehart and Dupre figure as useful dialogical counterparts to scientific history, they do not offer solutions to the novel's concerns about citizenship.

Ultimately, the question is whether an understanding of citizenship can be formed which recognizes the broader "stuff" of history, while rejecting both cynicism and the idealized citizenship envisioned by New Dealers. The epilogue offers a suggestion for how a critical, rather than merely cynical, citizenship might be configured. Sandwiched between the famous claim that the narrator "whipped it all except the mind, the mind" and the even more famous section on Louis Armstrong and "Old Bad Air," which provides a musical image of "dancing and ... diversity" the narrator makes this provocative claim:
And the mind that has conceived of a plan of living must never lose sight of the chaos against which that pattern was conceived. That goes for societies as well as for individuals. Thus, having tried to give pattern to the chaos within the pat- tern of your certainties, I must come out, I must emerge. ${ }^{40}$

This passage highlights the narrator's aim: to expose the phantasmagoric elements of Western fantasies by narrating the return of material and discursive elements rendered obsolete or invisible by modernization. In the process, it has shown those fantasies as being based not so much on progress but rather brutal, willful denial and repression. The displaced elements of history remain, though often in fragmentary form or attached to discourses that make their presence difficult to see; even the concept of the folk itself can obscure the continuity and modernity of vernacular culture. Critical citizenship, on the other hand, would need to keep these elements in view, recognize their presence, and thus resist their permanent incorporation into narratives disguising a will to power. This stance brings Invisible Man closer to 12 Million Black Voices, in which the latter's image of a "dark mirror," as Jeff Allred has noted, both creates a potential identification between black and white citizens and defers it by maintaining a view of racial power differentials. ${ }^{41}$ Like the dark mirror, Ellison's simultaneous view of pattern and chaos offers a perspective from which the narratives structuring power can be viewed and understood as contingent. Invisible Man never really offers a model citizen, or, more precisely, the several models it offers fail. Instead, the narrator's telling, right down to its ambiguities and ironies, performs critical citizenship, simultaneously keeping alive "the chaos" while bringing it into a visible pattern. ${ }^{42}$

While its most obvious target is American history itself, Invisible Man also offers a critical understanding of modernization, as a form of history in the making, by highlighting the need to see power interests involved in planning, the way that narratives are recruited to serve it, and, most importantly, alternatives to that pattern. This is not to say that Invisible Man is engaged in the exact same project as Jane Jacobs's The Death and Life of Great American Cities, 
with the latter's claim that modernist planners sought visual beauty at the cost of human thriving, but rather to suggest that the notion of citizenship Ellison's novel advances is one that, like Jacobs's book, asks readers to question the way the narrative of progress posits functional and dysfunctional elements and to recognize the latter's actual function. In fact, Invisible Man's critique of pattern might be brought to bear on the codification of Jacobs's ideas as a set of universal guidelines for urban redevelopment. Such ideas have helped to attract businesses and young professionals to urban neighborhoods - including both Harlem and the Deep Deuce neighborhood in Oklahoma City where Ellison grew up. However, they have also eroded existing populations while co-opting local history as a symbolic marker of authenticity that increases developers' profits. Invisible Man asks readers to restore the questions of social justice glossed over in gentrification plans. Similarly, on an initial glance, Invisible Man's stance might seem to fall in line with the key conservative narrative of the welfare state: the law of unintended consequences, in which attempts at regulation and planning invariably produce worse results than the market and serve primarily to increase governmental oversight over citizens' lives. This idea merely substitutes one logic of history (and space) for another. Invisible Man doesn't necessarily reject patterns and plans altogether but instead argues against their codification and reveals the way that, when set, they tend to erase people from history and its implied future. Ultimately, Ellison's "lower frequencies" signal a style of citizenship, a mode of engagement with the power embedded in narrative, rather than "a plan of living."

\section{Notes}

1. Ralph Ellison, The Collected Essays of Ralph Ellison, ed. John F. Callahan (New York: Modern Library, 2003), 321. Written in 1948, Ellison's essay was meant to be published in Life, alongside photographs by Gordon Parks, who had established his reputation as a photographer for the Farm Securities Administration under Roy Stryker. It was published eventually in Shadow and Act and later modified for Harper's Magazine in 1964. Arnold Rampersad has shown that themes from the essay echo throughout the landscape of Invisible Man. See Rampersad, Ralph Ellison: A Biography (New York: Vintage, 2008), 219-22.

2. Ellison, Collected Essays, 325.

3. Ellison, Invisible Man (New York: Vintage, 1989), 581. See Lesley Larkin, "Postwar Liberalism, Close Reading, and "You": Ralph Ellison's Invisible Man," Lit: Literature Interpretation Theory, 19, no. 3 (2008): 268-304, for an excellent summation of the sides and stakes of this debate. My argument in this paper brings together this line of criticism in Ellison studies with discussions of imagined citizenship in the Federal Writers' Project. For arguments about the FWP as a citizenship education project, see Christine Bold, The WPA Guides: Mapping America (Jackson: University Press of Mississippi, 1999); Jerrold Hirsch, Portrait of America: A Cultural History of the Federal Writers' Project (Chapel Hill: University of North Carolina Press, 2003); and Petra Schindler-Carter, Vintage Snapshots: The Fabrication of a Nation in the W.P.A. American Guide Series (New York: Peter Lang, 1999).

4. Ellison Interview with Ann Banks, 12 Dec 1977, RF Illustrated, Rockefeller Foundation 4, no. 2 (Sept. 1978)m Box 19, Folder 6, Ralph Ellison Papers, Library of Congress, Washington, DC (hereafter cited as Ellison Papers).

5. Ellison, Invisible Man, 581.

6. See Nils Gilman, Mandarins of the Future: Modernization Theory in Cold War America (Baltimore: Johns Hopkins University Press, 2003), and Kate Manzo, "Modernist Discourse and the Crisis of Development Theory," Studies in Comparative International Development, 26, no. 2 (summer 1991): 3-36, for discussions of international development in the postwar period. Gilman links prewar development ideas during the New Deal to postwar ones. Guy Reynolds, Apostles of Modernity: American Writers in the Age of Development. (Lincoln: University of Nebraska Press, 
2008) offers excellent discussion of how postwar American writers engaged with the development narrative.

7. This focus is symptomatic of a disciplinary issue. As opposed to cultural history more widely, literary studies of these decades have been focused heavily on a communist-anchored Left as the center of literary intellectual activity. The Popular Front, which blurred the lines between activity supporting the New Deal and support for communism, compounds difficulty in assigning origins to writers' intellectual and political positions. The importance of the Popular Front to literary intellectual activity in the 1930s is indisputable, but the coherence of the Popular Front and its implied ownership of progressive activity are not. All of the writers in this essay had a complex, developing relationship with both New Deal liberalism and communism, and it is the former that tends to be lost in analyses. Many African American writers, Ellison included, formulated some of their critique of welfare state liberalism from their engagement with communism, though other sources of suspicion and disagreement abounded as well, and many of these writers were well on their way to rejecting the Popular Front or forging alternative conceptions of political engagement by the time the literary responses discussed in this essay were written. A further difficulty arises in that, within published FWP documents, which served as publicity for New Deal programs, distinctions between liberal and communist positions cannot be discerned easily, though anticommunist critics of the FWP certainly found plenty in the guidebooks and other projects to support their views that the project was a hotbed of radicalism. Where Left counternarratives to the New Deal vision emerge within the FWP archive, they often did so in Writer's Union documents or, as I discuss later, in unpublished documents.

8. Jerrold Hirsch offers the most developed account bringing together New Deal -ra debates over the folk, how these shaped the FWP, and how Ellison's folklore investigations informed Invisible Man. See Hirsch, "Cultural Pluralism and Applied Folklore: The New Deal Precedent," in The Conservation of Culture: Folklorists and the Public Sector, Ed. Burt Feintuch, Lexington: Thiversity Press of Kentucky, 1988), 46--67 For other accounts, see George Hutchinson, The Harlem Renaissance in Black and White, (Cambridge, MA: Theknap Press of Harvard University Press, 1995); Robert G. O'Meally, The Craft of Ralph Ellison (Cambridge, MA: Harvard University Press, 1980); and Robert Baron, "I Saw Mrs. Saray Sitting on a Bombalerry': Ralph Ellison Collects Children's Folklore," Children's Folklore Review, 32 (2010): 23-52

9. See Michael Szalay, New Deal Modernism (Durham: Duke University Press, 2000); Susan Edmunds, Grotesque Relations: Modernist Domestic Fiction and the U.S. Welfare State (New York: Oxford University Press, 2008); Sean McCann, Gumshoe America: Hard-Boiled Crime Fiction and the Rise and Fall of New Deal Liberalism (Durham, NC: Duke University Press, 2000).

10. Reclassification Notice, John Cody to Ralph Ellison, Oct. 20, 1938, Box 19, Folder 6, Ellison Papers.

11. Ellison's recommendations included letters from the psychoanalyst Harry Stack Sullivan, for whom Ellison worked as a clerk and receptionist; William Sturgis of The Champion, where Ellison had worked as a member of the editorial staff and a free-lance reporter; and the Greater New York Coordinating Committee for Employment, for which Ellison had worked on publicity. See Box 1, Folder 17, Ellison Papers.

12. See Bold, WPA Guides, and Jerre Mangione, The Dream and the Deal: The Federal Writers' Project (Syracuse, NY: Syracuse University Press, 1996), 155-92, for discussion of these battles on the New York City FWP unit. Ellison's ratings as an employee were consistently "Excellent," and he was promoted to Senior Newspaperman in October 1938. See Box 19, Folder 6, Ellison Papers. Ellison also served on a Famous Trials subproject, which was one of several side projects of the comparatively well-staffed New York City office.

13. Hirsch, "The New Deal Precedent."

14. These interviews can be found in Box A648, The Records of the U.S. Works Progress Administration, Library of Congress (hereafter referred to as WPA Records).

15. Books that utilized information gathered by the FWP Negro History Unit included Gunner Myrdal, An American Dilemma: The Negro Problem and Modern Democracy (New York: Harper \& Brothers, 1944), and Horace Cayton and St. Clair Drake's Black Metropolis: A Study of Negro Life in a Northern City (New York: Harcourt Brace, 1945). The first book to utilize this information was written by the subunit director, Ottley, who took the draft materials for The Negro in New York as the project was winding down rather than turning them over to the federal government. See Ottley, New World-A Coming: Inside Black America (New York: Houghton Mifflin, 1943).

16. According to the Writers' Program Archives [Negroes of NY] NY 1939, Reels 1-5, Schomburg Research Library, other Negro History subunit project employees included Alyse Abrams, Wilfred R. Bain Everett Beanne, Waring Cuney, Wesley Curtwright, Norie Frazier, Sydney H. French, Arthur J. Gary, Lawrence Gellert, Sadie Hall, Odette Harper, Abram Hill, Oakley Johnson, Richard J Latimer, Mary McFadden, Claude McKay, Henry Lee Moon, S. Michelson, Vivian Norris, Richard Bruce Nugent, Carl Offord, Roi Ottley, Ted Poston, Harold Robinson, J.A. Rogers, Claire Spitz, Ellen Tarry, Lila Valde, Dorothy West, Simon Williamson, Ted Yates, and Wilbur Young. Though Ellison was primarily a reporter, he became the project's de facto ombudsman in 1940, when he was called in to identify and fix sections of The Negro in New York manuscript 
that were identified by Helen Boardman as being uncomfortably similar to James Weldon Johnson's Black Manhattan. There is little space here to discuss this incident, the relationship between The Negroes of New York and Black Manhattan, the relationship between Johnson himself and the FWP, and the evident antipathies between Boardman and Ottley. Ottley had indicated in a January 1940 letter to the director of the New York City FWP office, Frederick Clayton, that the project was finished and ready for approval. Ellison essentially saved the project as a whole, and Ottley as its editor, from an embarrassing plagiarism charge. However, the delay at a critical time for the FWP may well have ensured that the project was not published during its active years. See Ottley to Cayton, Jan. 4, 1940, Series 51, Roll 263, Municipal Archives of New York City (hereafter cited as MANYC holdings). See also "Editorial Report on State Copy" Apr. 25, 1940. Box 21, Folder 1, Ellison Papers, which details several problems with the draft manuscript. Ellison to Sumner Smith Apr. 22, 1940, MANYC Holdings indicates that Ellison was tasked with checking the draft. Several folders of chapter drafts that Ellison edited are in the Library of Congress holdings. See Box 21, Folders 1-7, Ellison Papers.

17. Interview with Eli Luster, Box 19, Folder 6, Ellison Papers. Barbara Foley also discusses this interview and links it to the character Wheatstraw. See Foley, Wrestling with the Left: The Making of Ralph Ellison's Invisible Man (Durham: Duke University Press, 2010), 204.

18. See Bold, The WPA Guides, 3-18, for a discussion of the guidebook form and the authority granted to it by the federal government. See also Marguerite Shaffer, See America First: Tourism and National Identity, 1905-1940 (Washington, DC: Smithsonian, 2001), on how travel writing has long supported various versions of a national imaginary.

19. See Szalay for a discussion of how Keynesian social insurance ideas influenced culture during this period and Hirsch's Portrait of America for discussion of pluralist aims. Alan Brinkley in End of Reform: New Deal Liberalism in Recession and War (New York: Alfred A. Knopf, 1995) best states the case for a break in the New Deal between earlier planning-oriented ideas and later social insurance ones. Ellis Hawley, The New Deal and the Problem of Monopoly: A Study in Economic Ambivalence (New York: Fordham University Press, 1995) best states the case for a more complex series of tensions. Daniel Rodgers's Atlantic Crossings: Social Politics in a Progressive Age (Cambridge, MA: Harvard UPiversity Press, 1998) traces the history of several Progressive discourses into the New Deal.

20. The Plow That Broke the Plains and The River, DVD, director Pare Lorentz (Naxos, 2007). The Tennessee Valley Authority (TVA) was perhaps the most complete iteration of this vision. TVA took a Southern Appalachian physical and social geography and, by subjecting it to a thorough planning process and investment through hundreds of work projects, transformed it into a modernized region expected to encourage the development of citizens ready to participate in the national community. Gilman, Mandarins of the Future, 38-39, links TVA and postwar international development ideas, suggesting that while TVA-style projects became unfeasible in the United States, the TVA still served as a model for international development projects.

21. "WPA and the Negro" Promotional Bulletin, Box 19, Folder 7, Ellison Papers. See also Julie A. Gallagher, Black Women and Politics in New York City (Urbana: University of Illinois Press, 2011), 50-51, on Roane's work with the Harlem Office of the New York State Labor Department.

22. Federal Writers' Project, The WPA Guide to New York City, rRprint (New York: Pantheon Books, 1982), 394. See also J. J. Butts, "Writing Projects: New Deal Guidebooks, Community, and Housing Reform in New York City," The Space between, Literature and Culture, 1914-5, 2, no. . (2006): 113-8. For historical discussions of Federal Housing Policy see Richard Plunz, A History of Housing in New York City, (New York: Columbia University Press, 1990); Joel Schwartz, The New York Approach: Robert Moses, Urban Liberals, and Redevelopment of the Inner City (Columbus: Ohio State University Press, 1993); and Lawrence J. Vale, From the Puritans to the Projects: Public Housing and Public Neighbors (Cambridge, MA: Harvard University Press, 2000).

23. Roi Ottley to Ralph Ellison, July 25, 1940, Box 19, Folder 5, Ellison Papers.

24. See J. J. Butts, "New World A-Coming: African American Documentary Intertexts of the Federal Writers' Project," African American Review 44, no. 4 (winter 2011): 649-66.

25. Zora Neale Hurston deserves mention here as her work illustrates conflicts between pluralism and control, but it does not fit with the urban focus of this section. The democratic elements of the FWP fit well with Hurston's beliefs and anthropological training. She recorded both folk stories and oral histories as a FWP researcher, though little of this material made it into the Florida guidebook. In light of her eventual opposition to welfare state liberalism, her 1939 novel Moses, Man of the Mountain (New York: J. B. Lippincott, 1939) reads as an ambivalent account of what happens when power is centralized: her Moses achieves great things, but only by self-delusion and ruthlessly cutting out opposing viewpoints and centralizing power.

26. Claude McKay, Harlem Negro Metropolis (New York: E. P. Dutton, 1940); Richard Wright, 12 Million Black Voices (New York: Viking, 1941); Wright, Native Son (New York: Harper \& Row, 1940).

27. Ellison interview with Ann Banks, Ellison Papers. 
28. The collection of literature by Federal Writers was named American Stuff (New York: Viking Press, 1937). Richard Wright's essay “The Ethics of Living Jim Crow: An Autobiographical Sketch" was first published in this volume.

29. Ellison, Invisible Man, 241-42.

30. See Ellison, "Folklore, Harlem Children's Rhymes," Dec. 15, 1939, Box A648, Folklore Project Folder, WPA Records. The draft indicates Ellison interviewed and recorded songs near PS89 at 134th St. and 135 th St.

31. Ellison, Invisible Man, 273.

32. Marc Conner, "The Litany of Things: Sacrament and History in Invisible Man," in Ralph Ellison and the Raft of Hope: A Political Companion to Invisible Man, ed. Lucas E. Morel. (Lexington: University Press of Kentucky, 2004), 172-73. Conner also ties in this passage to the narrator's cognizance of community.

33. Conner, "Litany," 173, also makes this link to Benjamin. See Benjamin, "Theses on the Philosophy of History," Illuminations, trans. Hannah Arendt (New York: Schocken Books, 1968), 253-64.

34. A draft of chapter XVIII of The Negroes in New York includes the following:

In the Spring of 1938 Harlem adopted a series of black outs every Tuesday night. There were no threats of air raids; black-outs was the strategy initiated by the Greater New York Co-ordinating Committee for Employment in its battle against the Consolidated Edison Electric and Gas Company to force them to hire Negroes without discrimination.

Ellison had worked for this organization. The draft also notes coordinated activities against Bell Telephone and against discrimination in hiring at the 1939 World's Fair. See Box 21, Folder 7, Ellison Papers.

35. Alan Nadel, Invisible Criticism: Ralph Ellison and the American Canon (Iowa City: University of Iowa Press, 1988), 86; Lewis Mumford, The Golden Day: A Study in American Literature and Culture, (New York: W. W. Norton, 1933). See also Mumford, The Culture of Cities (New York: Harcourt, Brace, \& World, 1938).

36. Ellison, Invisible Man, 504.

37. Ibid., 441. See A. Yemisi Jimoh, Spiritual, Blues and Jazz People in African American Fiction (Knoxville: University of Tennessee Press, 2002), 148-50, for a discussion of Rinehartism as an idea that the narrator rejects as a philosophy of citizenship while maintaining awareness of its useful evasive and critical stance.

38. See Dominic J. Capeci, Jr., The Harlem Riot of 1943 (Philadelphia: Temple University Press, 1977), for a history of the 1943 riot.

39. George E. Kent, "Ralph Ellison and the Afro-American Folk and Cultural Tradition," in The Critical Response to Ralph Ellison, ed. Robert J. Butler (Westport, CT: Greenwood Press, 2000): 51-57, 54.

40. Ellison, Invisible Man, 580-81.

41. Jeff Allred, "From Eye to We: Richard Wright's 12 Million Black Voices, Documentary, and Pedagogy," American Literature, 78, no. 3 (2006): 578-79.

42. James C. Scott, in Seeing like a State: How Certain Schemes to Improve the Human Condition Have Failed (New Haven, CT: Yale University Press, 1998), argues that the first task of state-directed development has been making complexity illegible through reduction and classification. Ellison's emphasis on chaos, like Benjamin's moment of crisis in "Theses on the Philosophy of History," suggests possible forms of intelligibility that preserve not only awareness but also the value of those things that fall outside developmental schemes. Former U.S. Secretary of Defense Donald Rumsfeld illustrated the plenitude of these when, in a 2002 speech about the deflated weapons of mass destruction rationale for the Iraq War, he described the "the known unknowns," and "the unknown unknowns" to which he later added another category "the unknown knowns." 